\title{
Penerapan Media Interaktif “KNS" untuk Siswa Autis
}

\author{
Sartika Rahmawati, Asim \\ Universitas Negeri Malang \\ E-mail: sartikarahmawati999@gmail.com
}

\begin{abstract}
Abstrak: Siswa autis adalah anak yang memiliki dunianya sendiri . Hal ini menjadi salah satu penyebab siswa autis lemah dalam mengenal konsep bunyi. Untuk meningkatkan kemampuan identifikasi bunyi siswa autis penggunaan media interaktif berbasis audio dan visual dengan nama Media Interktif KNS (kenal nama dan suara). Penelitian ini menggunakan rancangan penelitian kuantitatif dengan metode pre eksperimen dengan desain one group pretest-posttest. Berdasarkan hasil yang diperoleh menggunakan Uji Wilcoxon disimpulkan bahwa terdapat pengaruh yang signifikan penggunaan Media Interaktif KNS terhadap kemampuan identifikasi bunyi siswa autis kelas II SLB Autis Laboratorium Universitas Negeri Malang.
\end{abstract}

Kata Kunci: autis, Media Interaktif KNS, kemampuan identifikasi bunyi.

Autistic students are children who have their own world. This became one of the causes of autistic students weak in recognizing the concept of sound. To improve the autistic students' sound recognition ability using audio and visual interactive media with the name of KNS Interactive Media (know name and sound). This research uses quantitative research design with pre experiment method with one group pretest-posttest design. Based on the results obtained using Wilcoxon Test concluded that there is a significant effect of KNS Media on the ability to identify the sounds of autism students class II SLB Autism Laboratory State University of Malang.

Keywords: Autis, Interaktive Media KNS, the ability to identify sounds.

Autis merupakan gangguan perkembangan neurobiologis sehingga kemampuan berkomunikasi dan berintegrasi dengan lingkungan terganggu. Ketidakmampuan autis untuk membangun hubungan dengan orang lain dikarenakan terganggunya pada kemampuan untuk mengalami gangguan dalam belajar. Menurut (Koswara 2013) terdapat 3 masalah dalam belajar autis, yaitu 1) komunikasi, 2) interaksi sosial, 3) perilaku. Selama kegiatan belajar, siswa autis sulit menerima materi yang telah disampaikan oleh guru. Berbeda dengan siswa pada umumnya ketika diberikan simulus dalam belajarnya, mereka akan menerapkan apa yang diberikan gurunya karena menerapkan materi dari proses belajar adalah bagian dari proses kemandirian.

Siswa autis adalah anak yang memiliki dunianya sendiri. Sehingga menyebabkan siswa autis lemah dalam merespon lingkungan sekitar. Begitu juga dalam kegiatan pembelajaran mengenal konsep bunyi, siswa autis kurang merespon materi yang disampaikan guru. Sesuai dengan pendapat Panggabean (2014) yakni siswa autis kurang dalam merespon li ngkungan sebagaimana mestinya dan memperlihatkan kurangnya kemampuan komunikasi dan sering merespon lingkungan dengan cara yang unik.

Bunyi selalu ada dilingkungan sekitar dan selalu menjadi bagian aktifitas sehari-hari. Konsep pemahaman bunyi merupakan pemahaman dasar yang telah siswa umum kuasai sejak lama. Namun hal ini berbeda dengan siswa autis, karena siswa autis memiliki kemampuan merespon lingkungan berbeda dengan anak pada umumnya. Pemahaman tentang konsep bunyi pada siswa autis yang rendah menyebabkan kesulitan membedakan objek berdasarkan bunyi khas atau suatu objek yang memiliki suara yang sama. Pentingnya konsep bunyi dalam komunikasi seharihari menjadikan pembelajaran tentang konsep bunyi ini perlu untuk diulas dan diajarkan kepada siswa autis secara mendalam.

Seorang guru harus lebih kreatif ketika memberikan materi dalam kegiatan pembelajaran. Selain itu, guru harus menyesuaikan kebutuhan dan kemampuan siswa sehingga materi yang disampaikan dapat terserap dengan baik. Ariani \& Haryanto (2010) menjelaskan bahwa suatu materi pembelajaran harus didesain sedemikian rupa sehingga mengakomodasi banyak tipe pembelajaran dan gaya belajar.

Pengunaan media dalam pembelajaran perlu dipertimbangkan agar sesuai dengan karakteristik belajar siswa. Sehingga kompetensi yang telah ditetapkan dapat dicapai dengan maksimal. Pembelajaran identifikasi bunyi umumnya dibantu dengan menggunakan tape recorder dan kartu gambar. Penggunaan media tape recorder dan kartu gambar yang digunakan saat kegiatan mengenal konsep bunyi kurang mengakomodasi kebutuhan belajar siswa autis. Pengunaan media pembelajaran audio dan visual yang terpisah ini akan menyulitkan siswa autis untuk berfikir, sehingga guru harus mengajarkan materi secara berulang-ulang. 
Perangkat lunak yang mampu mengabungkan keduanya materi pembelajaran berbasis audio dan visual salah satunya adalah powerpoint. Powerpint dapat mengatasi kelemahan media pembelajaran mengunakan audio-visual yang terpisah Keunggulan pemakaian powerpoint sebagai media interaktif pada pembelajaran identifikasi bunyi mudah digunakan terutama untuk mengabungkan dua unsur yang terpisah yaitu audio dan visual.

Memodifikasi pembelajaran identifikasi bunyi dengan media yang mengutamakan visual dan audio perlu diupayakan supaya terencipta suasana belajar yang menyenangkan. Siswa autis SLB Autis Laboratorium Universitas Negeri Malang, lima diantaranya kurang mampu merespon keadaan lingkungan sekitar termasuk kemampuan mengidentifikasi bunyi-bunyi di sekitar lingkungan. Pada saat kegiatan pembelajaran kemampuan visual siswa autis cenderung lebih dominan dibandingkan dengan kemampuan audionya atau pendengaran. Ketika menerima materi pembelajaran yang bersifat non visual atau abstrak anak autis lebih sulit untuk memahami pembelajaran. Hal ini dikarenakan siswa autis memiliki karakteristik belajar visual learning, siswa lebih mudah menerima informasi menggunakan gambar atau isyarat tubuh. Dettmer, dkk (dalam Nirahma \& Yuniar, 2012) menyatakan bahwa dalam kegiatan pembelajaran individu dengan gangguan autis lebih mudah untuk memperoleh informasi secara dari pada stimulus pendengaran.

Penggunaan media interaktif dalam proses pembelajaran yang mengabungkan audio dan visual diharapkan lebih efektif digunakan dalam pembelajaran identifikasi bunyi untuk siswa autis. Hal ini sesuai dengan karakteristik siswa autis yang lebih kepada visual terutama pada pembelajaran identifikasi bunyi.

Media Interaktif KNS singkatan dari media kenal nama dan suara merupakan media interaktif yang menggunakan auditori dan juga visual, yang menjelaskan mengenal nama dan suara hewan \& alat transportasi. sehingga membatu siswa autis untuk memahami pesan yang disampaikan pada pembelajaran identifikasi bunyi. Penggunaan Media Interaktif KNS ini akan membuat subjek lebih tertarik dalam mengikuti pembelajaran.

Penggunaan Media interaktif KNS dalam pembelajaran identifikasi bunyi akan mengurangi pembelajaran dalam bentuk metode ceramah. Jika materi identifikasi bunyi hanya dijelaskan secara lisan maka siswa autis akan mudah lupa dikarenakan daya ingatnya yang terbatas. Menurut Hendrawan (2010) dalam kegiatan pembelajaran siswa autis akan lebih mudah untuk mengingat, apabila media yang digunakan berupa gambar dari benda-benda, kejadian, tingkah laku maupun konsep-konsep abstrak. Melalui media gambar pesan yang disampaikan pada saat kegiatan pembelajaran akan mudah diterima dan relatif permanen dalam benaknya.

Pengunaan Media interaktif KNS dalam kegiatan pembelajaran diharapkan memiliki banyak manfaat terhadap pembelajaran identifikasi bunyi, dengan demikian dilakukan penelitian dengan judul "Pengaruh Penerapan Media interaktif KNS dalam Meningkatkan Kemampuan Mengidentifikasi Bunyi bagi Siswa Autis SLB Autis LaboratoriumUniversitas Negeri Malang”.

\section{METODE}

Penelitian bertujuan mengetahui pengaruh penerapan Media Interaktif KNS dalam meningkatkan kemampuan mengidentifikasi bunyi siswa autis di SLB Autis Laboratorium Universitas Negeri Malang. Desain penelitian ini adalah pre experiment designs. Pre experiment design merupakan desain penelitian yang melibatkan pengaruh variabel luar terhadap terbentuknya variabel dependen. Bentuk penelitian yang digunakan adalah One Grup Pretest-Posttest Design yang dikenal pula sebagai design "sebelum dan sesudah"

Variabel bebas dalam penelitian ini adalah pembelajaran mengunakan Media Interaktif KNS. Variabel terikat adalah kemampuan identifikasi bunyi siswa autis.

Populasi dari penelitian ini adalah siswa autis di SLB Autis Laboratorium Universitas Negeri Malang. Teknik yang digunakan dalam pemilihan subjek adalah Non probability sampling dengan mengunakan teknik sampling pertimbangan atau sampling bertujuan (purposive sampling).

Subjek yang diambil pada penelitian ini adalah siswa autis dengan kemampuan mengidentifikasi bunyi rendah dan lemah dalam merespon lingkungan. Berdasarkan teknik sampling didapat jumlah subjek yang diteliti sebanyak 5 siswa autis yang terdiri dari 5 laki-laki.

Instrumen penelitian berupa instrumen perlakuan dan instrumen pengukuran. Instrumen perlakuan berupa RPP dengan Media Interaktif KNS. RPP disusun berdasarkan kebutuhan siswa untuk mempelajari identifikasi bunyi. Instrumen pengukuran berupa soal untuk mengidentifikasi kemampuan siswa autis terhadap identifikasi bunyi. Instrumen pengukuran berupa 5 soal identifikasi bunyi hewan dan 5 soal identifikasi bunyi alat transportasi berdasarkan suara khas.

Uji validitas berupa validitas isi pada instrumen perlakuan dan instrumen pengukuran. Validitas isi berdasarkan penilaian dan pertimbangan dosen PLB Universitas Negeri Malang dan guru SLB Autis Laboratorium UM. Validator (ahli) memberikan skor pada masing-masing soal pada instrumen perlakuan dan pengukuran. Langkah untuk mengetahui validitas isi adalah membandingkan instrumen. 
Tabel 1 Hasil Rekapitulasi Nilai Pretest dan Posttest Kemampuan Identifikasi Bunyi

\begin{tabular}{llll}
\hline No. & Nama & Nilai Pretest & Nilai Posttest \\
\hline 1. & AN & 75 & 91,6 \\
2. & KV & 48 & 100 \\
3. & RH & 41,5 & 88,3 \\
4. & BG & 38 & 98,3 \\
5. & MS & 45 & 81,5 \\
Total & & 247,5 & 459,7 \\
\multicolumn{2}{l}{ Rata-rata } & 49,5 & 91,1 \\
\hline
\end{tabular}

Gambar 1 : Grafik Rekapitulasi Nilai Pretest dan Posttest Kemampuan Identifikasi Bunyi Siswa Auti

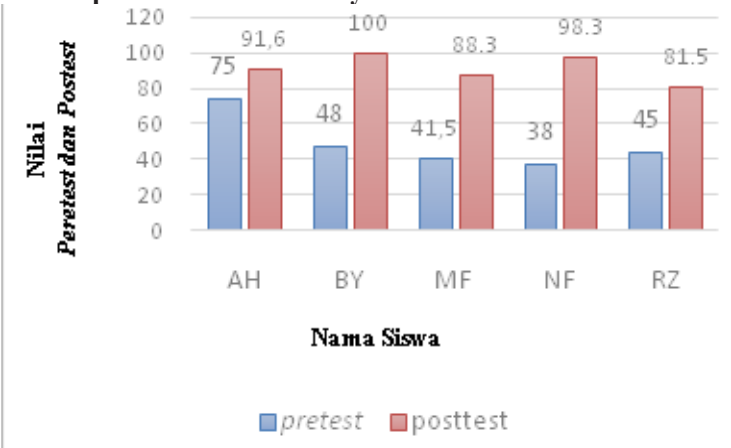

Uji coba soal pada penelitian ini tidak dilakukan karena subjek penelitian adalah siswa berkebutuhan khusus dengan gangguan autis. Siswa autis memiliki karakteryang berbeda-beda dari setiap individunya. Sehingga instrumen tidak bisa diuji reabilitasnya.

Pengumpulan data dalam penelitian yakni tahap persiapan, tahap pelaksanaan dan tahap akhir penelitian. Analisis data menggunakan statistik deskriptif dan Statistik Inferensial. Statistik deskriptif digunakan untuk mengetahui kemampuan siswa autis dalam mengidentikasi bunyi sebelum dan sesudah diberikan perlakuan berupa Media Interaktif KNS. Statistik inferensial menggunakan uji statistik nonparametrik dikarenakan data yang akan dianalisis berupa data ordinal atau data berjenjang. Statistik nonparametrik tidak menuntut terpenuhi banyak asumsi, seperti distribusi data tidak normal.

Teknik analisis data yang sesuai untuk menguji hipotesis penelitian diterima atau ditolak dalam penelitian ini adalah menggunakan Wilcoxon test model matched pairs dengan $\alpha 0,05$.

Subjek yang digunakan peneliti dalam penelitian ini kurang dari 25 yaitu 5 siswa autis, sehingga tes Uji Wilcoxon dengan taraf nyata atau signifikan yang digunakan adalah $\alpha=5 \%=0,05$. Hipotesis kerja yang akan diuji adalah terdapat pengaruh yang signifikan pada penggunaan Media Interaktif KNS terhadap kemampuan identifikasi bunyi siswa autis di SLB Autis Laboratorium Universitas Negeri Malang. Dasar pengambilan keputusan adalah sebagai berikut. diterima apabila $\mathrm{T}$ hitung $\geq \mathrm{T}$ table, ditolak jika $\mathrm{T}$ hitung $<\mathrm{T}$ tabel

\section{HASIL DAN PEMBAHASAN}

\section{Hasil}

Kegiatan pretest dilaksanakan pada satu kelas yaitu kelas II Autis SLB Autis Laboratorium Universitas Negeri Malang. Soal yang diberikan saat Pretest terdiri dari dua macam soal. Soal yang pertama berupa memberi tanda cek list $(\sqrt{ })$ gambar berdasarkan suara. Pada soal yang kedua mencocokan suara sesuai dengan kartu gambar

Pada saat pretest siswa autis mengalami hambatan dalam mengerjakan soal identifikasi bunyi. Hal ini dibuktikan dari jawaban siswa autis ketika mengerjakan soal. Beberapa peserta siswa autis tidak memberikan respon ketika peneliti meminta untuk menebak bunyi yang didengar. Ketika peneliti meminta siswa autis untuk mencocokan gambar dengan suaranya adakalanya jawaban yang diberikan siswa kurang tepat. Misalnya saat peneliti meminta siswa autis mencocokan suara sapi dengan gambar sapi akan tetapi gambar yang dia ambil adalah gambar kambing. Berdasarkan data pretest sebelum siswa autis mendapatkan perlakuan menggunakan Media Interaktif KNS. Diketahui skor akhir pretest dengan rata-ratanya 49,5 dengan nilai maksimal 100.

Kegiatan posttest dilaksanakan setelah pemberian perlakuan ke tiga. Pada kegiatan posttest soal yang diberikan pada tahap posttest sama dengan soal yang diberikan pada tahap pretest. Hal ini digunakan sebagai pembanding setelah siswa autis diberikan perlakuan berupa Media Interaktif KNS.

Pada saat posttest siswa mampu mengerjakan dengan baik dan dapat mengikuti arahan dari peneliti. Adapun hasil posttest kemapuan identifikasi bunyi dengan rata-rata 91,2 dengan nilai maksimal 100. Hal ini menunjukan terdapat peningkatan hasil belajar siswa autis terhadap kemampuan identifikasi bunyi.

Setelah mengetahui hasil dari nilai pretest dan posttest maka dilakukan rekapitulasi untuk mengetahui peningkatan dari hasil belajar setelah diberikan perlakuan. Berikut ini hasil rekapitulasi nilai pretest.

Berdasarkan data dari Tabel 1, data dari 5 orang siswa secara keseluruhan mengalami peningkatan kemampuan identifikasi bunyi. Adapun diagram batang yang disajikan gambar 1

Berdasarkan penjelasan Tabel 1 dan Grafik1 diatas, data tersebut menunjukkan bahwa hasil posttest yang lebih tinggi dibandingkan data hasil pretest dengan selisih rata-rata sebesar 42,4 . Skor nilai pretest lebih rendah dari nilai posttest. Nilai pretest dibawah 65 sedangkan nilai posttest diatas 65 , sebagai standar tercapainya KKM di SLB. Berdasarkan data yang diperoleh hasil data tersebut menunjukkan bahwa terdapat perbedaan sebelum dan sesudah dilakukan perlakuan menggunakan Media Interaktif KNS siswa autis. 
Tabel 2 Hasil Uji Wilcoxon.

\begin{tabular}{|c|c|c|c|c|c|c|}
\hline \multirow[b]{2}{*}{ No } & \multicolumn{2}{|c|}{ Nilai } & \multirow{2}{*}{$\begin{array}{c}\text { Beda } \\
\text { (X- } \\
\text { Y) }\end{array}$} & \multirow{2}{*}{$\begin{array}{l}\text { Jen- } \\
\text { jang }\end{array}$} & \multicolumn{2}{|c|}{ Tanda } \\
\hline & $\begin{array}{c}\text { Pretest } \\
\text { (X) }\end{array}$ & $\begin{array}{l}\text { Posttest } \\
\text { (Y) }\end{array}$ & & & Positif & $\begin{array}{c}\text { Nega- } \\
\text { tif }\end{array}$ \\
\hline 1 & 75 & 91,6 & $+16,6$ & 5 & +5 & - \\
\hline 2 & 48 & 100 & +52 & 2 & +2 & - \\
\hline 3 & 41,5 & 88,3 & $+46,8$ & 3 & +3 & - \\
\hline 4 & 38 & 98,3 & $+60,3$ & 1 & +1 & - \\
\hline 5 & 45 & 81,5 & $+36,5$ & 4 & +4 & - \\
\hline & \multicolumn{4}{|c|}{ Jumlah } & +15 & $\begin{array}{c}\quad \mathrm{T} \\
\text { hitung } \\
=0\end{array}$ \\
\hline
\end{tabular}

Data rekapitulasi dihitung menggunakan Uji Wilcoxon. Berikut penjabaran hasil data pretest dan posttest menggunakan Uji Wilcoxon. IPada Tabel 2.

Berdasarkan hasil perhitungan tabel yang diambil dari nilai terkecil diatas diperoleh $\mathrm{T}_{\text {hitung }}=0$. Sedangkan harga $T_{\text {tabel }}$ dengan Taraf nyata $(\alpha),(\alpha 0,05$ dan $n=5)$ sebesar 1. Berdasarkan kriteria pengujian yang telah ditetapkan, dinyatakan bahwa Hipotesis kerja diterima karena $\mathrm{T}_{\text {hitung }}<\mathrm{T}_{\text {tabel }}$. dapat diartikan bahwa $\mathrm{T}_{0}=0<$ $\mathrm{T}_{\text {tabel }}=1$ atau $0<1$.

Kesimpulan dari hasil di atas maka hipotesis diterima, yang artinya terdapat pengaruh yang signifikan pada penggunaan Media Interaktif KNS terhadap kemampuan identifikasi bunyi siswa autis SLB Autis Laboratorium Universitas Negeri Malang.

\section{Pembahasan}

Kemampuan siswa autis dalam mengidentifikasi bunyi sebelum menggunakan Media Interaktif KNS diketahui melalui pretest. Melalui hasil pretest dapat diketahui kemampuan siswa autis sebelum menggunakan Media Interaktif KNS. Kemampuan siswa autis dalam mengidentifikasi bunyi masih kurang, dibuktikan dengan nilai rata-rata siswa autis yang jauh dari standar KKM yakni 49,5. Kurangnya kemampuan identifikasi bunyi karena siswa autis kurang mampu mengidentifikasi bunyi berdasarkan suara yang sama. Misalnya pada kemampuan mengidentifikasi suara hewan siswa autis sulit membedakan suara kambing dan suara sapi, dikarenakan ciri-ciri kambing dengan sapi hampir sama. Selain itu, siswa autis masih sulit kosentrasi untuk menjawab soal yang diberikan karena pilihan gambar banyak. Pada mengidentifikasi bunyi alat transportasi siswa autis merasa kesulitan untuk menjawab terutama suara helikopter

Ketidak mampuan siswa autis dalam menjawab soal dikarenakan kurangnya kosentrasi siswa autis dikarenakan siswa autis mengalami gangguan pada sensorik. Kurdi(2009) menyatakan siswa autis memiliki gangguan pada pengolahan sensorik sehingga muncul perilaku hiperaktif, gangguan motorik, tonus otot yang lemah, dan kesulitan berkonsentrasi. Masalah dalam sensorik juga menyebabkan anak dengan autisme tidak relevan dalam menyaring input-input sehingga seringkali gagal dalam mengolah informasi penting dan cenderung mudah stres dan cemas.

Berdasarkan hasil pretest disimpulkan bahwa sebelum siswa autis diberikan perlakuan menggunakan Media Interaktif KNS. Siswa autis belum mampu mengidentifikasi bunyi dengan baik dan benar. Siswa autis adalah anak yang memiliki dunianya sendiri. Hal ini menjadi salah satu penyebab siswa autis lemah dalam merespon keadaan lingkungan sekitar. Begitu juga dalam kegiatan pembelajaran mengenal konsep bunyi, siswa autis kurang merespon materi yang disampaikan guru. Hal ini sesuai dengan pendapat Panggabean (2014) anak autis kurang dalam merespon lingkungan sebagaimana mestinya dan memperlihatkan kurangnya kemampuan komunikasi dan sering merespon lingkungan dengan cara yang unik.

Kemampuan siswa autis dalam mengidentifikasi bunyi setelah menggunakan media interaktif KNS diketahui melalui postest. Pada kondisi setelah diberikan perlakuan, kemampuan identifikasi bunyi siswa autis mengenal hewan dan alat transportasi mengalami peningkatan. Perbedaan kemampuan identifikasi bunyi dilihat dari rata-rata posttest 91,2 dan rata-rata hasil pretest 49,5. Perbedaan rata-rata tersebut dikarenakan adanya perlakuan menggunakan Media Interaktif KNS, Sebelum diberikan posttest siswa autis diberikan perlakuan menggunakan Media Interaktif KNS sebanyak tiga kali

Pada kegiatan pembelajaran siswa autis dituntut aktif, saat pembelajaran identifikasi bunyi menggunakan Media Interaktif KNS kegiatan berupa menunjuk gambar sesuai dengan suara dan mencocokan gambar dengan kartu gambar. Pembelajaran indentifikasi bunyi menggunakan Media Interaktif KNS lebih mengutamakan pada visual dikarenakan belajar autis cenderung kepada visualnya daripada audionya. Sejalan dengan pendapat Dettmer, dkk (dalam Nirahma \& Yuniar, 2012) menyatakan bahwa individu dengan gangguan autis lebih mudah untuk memperoleh informasi secara visual dari pada stimulus pendengaran. Adapun manfaat pembelajaran visual untuk siswa autis menyatakan bahwa dukungan visual memberikan peluang kepada siswa autis untuk belajar lebih cepat, mengurangi frustasi, kecemasan, dan menambah kemadirian (Hayes, dkk 2000).

Pembelajaran identifikasi bunyi menggunakan Media Interaktif KNS dapat mempengaruhi hasil belajar pada siswa autis kelas II. Hal ini dibuktikan melalui hasil analisis posttest dari 5 peserta didik dengan memperoleh nilai rata-rata 91,6,100, 88,3, 98, 3, dan 81,5 dibandingkan dengan nilai saat pretest yaitu: 75,48, 41,5, 38, 45 .

Adapun penelitian serupa penggunaan media pembelajaran interaktif untuk siswa autis dengan 
judul penelitian "Penggunaan Media Film Animasi Untuk Meningkatkan Kemampuan Berbicara Anak Autis" yang dilakukan oleh (Wulandari, Annisa. 2016: 101). Hasil penelitiannya menyatakan bahwa penggunaan media film animasi dapat meningkatkan kemampuan berbicara anak autis kelas III SD di SLB Rela Bhakti I Gamping. Berdasarkan paparan diatas disimpulkan pembelajaran menggunakan Media KNS dapat digunakan untuk meningkatkan kemampuan identifikasi bunyi siswa autis SLB Autis Laboratorium Universitas Negeri Malang.

\section{KESIMPULAN DAN SARAN}

\section{Kesimpulan}

Berdasarkan hasil penelitian hasil penelitian yang dilakukan, disimpulkan bahwa terdapat pengaruh yang signifikan penggunaan Media Interaktif KNS terhadap kemampuan identifikasi bunyi siswa autis kelas II SLB Autis Laboratorium Universitas Negeri Malang

\section{Saran}

Adapun saran dalam penelitian ini Berdasarkan pada kegitan penelitian yang dilakukan, maka peneliti mengajukan beberapa saran sebagai berikut. Bagi peneliti selanjutnya, disarankan dapat melanjutkan penelitian menggunakan pembelajaran menggunakan Media Interaktif KNS namun tidak hanya terbatas pada suara hewan atau alat transportasi. Media Interaktif KNS perlu adanya modifikasi untuk menyesuaikan cara belajar peserta didik terutama anak dengan hambatan khusus. .

\section{DAFTAR PUSTAKA}

Ariyani. (2010) Pembelajaran Multimedia di Sekolah. Jakarta: PT. Prestasi Pustakaraya.

Hasan, (2006) Analisis Data Penelitian dengan Statistik. Jakarta: PT. Bumi Aksara.

Fauziah, (2009) Strategi dan Teknik Pembelajaran pada Anak dengan Autisme, (Online), 29 (1):1425. (forumkependidikan.unsri.ac.id), diakses 3 Juni 2017.

Hayes. (2010) Interactive Visual Supports for Children with Autism. Focus on Autism and Other Developmental Disabilities, (Online),14:663-680, (https://pdfs.semanticscholar.org), diakses 03 Juni 2017.

Hendrawan, Rizal. (2004) CD Multimedia Interaktif Komunikasi Visual untuk Anak Penderita Autis. Tugas Akhir. Universitas Sebelas Maret Surakarta.

Kalsum. (2014) Pemantauan Peningkatan Kemampuan Pengenalan Hewan Berkaki Empat dengan Program Pembelajaran Interaktif bagi
Siswa Autis. Jurnal Ilmiah Go Infotech. 20 (2). (Online). (http://jurnal.stmik-aib.ac.id), diakses 23 Desember 2016

Koswara. (2013) Pendidikan Anak Berkebutuhan Khusus Autis. Jakarta Timur: Luxima Metro Media.

Nirahma, (2012) Metode Dukungan Visual pada Pembelajaran Anak dengan Autisme, (Jurnal). Psikologi Klinis dan Kesehatan Mental, Vol 1, No 02, diakses 2 Desember 2016.

Panggabean, (2014) Analisis Kemampuan Berkomunikasi Verbal dan Nonverbal pada Anak Penderita Autis (Tinjauan Psikolinguistik). Skripsi tidak diterbitkan. Medan. Universitas Negeri Medan.

Wulandari, (2016) Penggunaan Media Film Animasi untuk Meningkatkan Kemampuan Berbicara Anak Autis Kelas III SDDI SLB Relabhakti I Gamping. Skripi tidak diterbitkan. Yogyakarta:UNY. 